\title{
Optimism, pain coping strategies and pain intensity among women with rheumatoid arthritis
}

\section{Optymizm, strategie radzenia sobie z bólem i jego nasilenie u pacjentek $z$ reumatoidalnym zapaleniem stawów}

\author{
Zuzanna Kwissa-Gajewska1, Marzena Olesińska², Anna Tomkiewicz ${ }^{2}$ \\ ${ }^{1}$ University of Social Sciences and Humanities, Warsaw, Poland \\ Institute of Rheumatology, Warsaw, Poland \\ ${ }^{1}$ Szkoła Wyższa Psychologii Społecznej w Warszawie, Polska \\ ${ }^{2}$ Instytut Reumatologii im. prof. dr hab. med. Eleonory Reicher w Warszawie, Polska
}

Key words: optimism, pain coping strategies, pain intensity, rheumatoid arthritis.

Słowa kluczowe: optymizm, strategie radzenia sobie z bólem, ból, reumatoidalne zapalenie stawów.

\begin{abstract}
Sum mary
Objectives: According to the biopsychosocial model of pain, it is a multidimensional phenomenon, which comprises physiological (sensation-related factors), psychological (affective) and social (socio-economic status, social support) factors. Researchers have mainly focused on phenomena increasing the pain sensation; very few studies have examined psychological factors preventing pain. The aim of the research is to assess chronic pain intensity as determined by level of optimism, and to identify pain coping strategies in women with rheumatoid arthritis (RA).

Material and methods: A survey was carried out among 54 women during a 7-day period of hospitalisation. The following questionnaires were used: LOT-R (optimism; Scheier, Carver and Bridges), the Coping Strategies Questionnaire (CSQ; Rosenstiel and Keefe) and the 10-point visual-analogue pain scale (VAS).

Results: The research findings indicate the significance of optimism in the experience of chronic pain, and in the pain coping strategies. Optimists felt a significantly lower level of pain than pessimists. Patients with positive outcome expectancies (optimists) experienced less pain thanks to replacing catastrophizing (negative concentration on pain) with an increased activity level. Regardless of personality traits, active coping strategies (e.g. ignoring pain sensations, coping self-statements - appraising pain as a challenge, a belief in one's ability to manage pain) resulted in a decrease in pain, whilst catastrophizing contributed to its intensification. The most common coping strategies included praying and hoping. Employment was an important demographic variable: the unemployed experienced less pain than those who worked. Conclusions: The research results indicate that optimism and pain coping strategies should be taken into account in clinical practice.
\end{abstract}

\section{Streszczenie}

Cel pracy: Według biopsychospołecznego modelu ból jest zjawiskiem wielowymiarowym, składającym się z czynników: fizjologicznych (odczucie bólu), psychologicznych (poznawczych, emocjonalnych) i społecznych (status socjoekonomiczny, wsparcie społeczne). W dotychczasowych badaniach skupiano się głównie na właściwościach wzmacniających nieprzyjemne doznanie, niewiele prac dotyczyło czynników obniżających jego nasilenie. Celem badania było sprawdzenie różnic w zakresie odczuwania bólu przewlekłego uwarunkowanych poziomem optymizmu i strategii radzenia sobie z bólem u kobiet z reumatoidalnym zapaleniem stawów (RZS).

Materiał i metody: Badaniami kwestionariuszowymi objęto 54 kobiety w wieku 24-65 lat podczas 7-dniowej hospitalizacji. Zastosowano jednorazowo kwestionariusze LOT-R (optymizm; Scheier, Carver i Bridges), Kwestionariusz strategii radzenia sobie z bólem (CSQ; Rosenstiel i Keefe) oraz 10-stopniową wizualno-analogową skalę bólu (VAS), uzupetnianą przez pacjentki w czasie kolejnych 7 dni hospitalizacji.

Wyniki: Wykazano istotne znaczenie optymizmu dla odczuwanego bólu przewlekłego oraz stosowanych strategii radzenia sobie z nim. Osoby oczekujące pozytywnych wyników swoich działań (wysoki optymizm) doświadczały słabszego bólu niż pesymiści, stosując zwiększoną aktywność behawioralną, nadmiernie nie koncentrując się i nie przeceniając doznań bólowych (katastrofizowania). Niezależnie od uwarunkowań osobowościowych aktywne radzenie sobie poprzez ignorowanie doświadczeń zmysłowych oraz traktowanie bólu jako wyzwania i przekonanie, że można sobie z nim poradzić (deklarowanie radzenia sobie), pozytywnie wpływało na obniżenie bólu, a katastrofizacja - na jego nasilenie. Najczęściej stosowaną strategią radzenia sobie było modlenie się lub pokładanie nadziei. 
Particular attention should be given to those who have negative outcome expectations, which in turn determine strong chronic pain regardless of coping strategies. Intensification of positive outcome expectations and seeking benefits in the RA experience could therefore constitute effective techniques in the clinical therapy process.
Istotną zmienną demograficzną, wpływającą na poziom nieprzyjemnego odczucia, było zatrudnienie - osoby bezrobotne odczuwały słabszy ból niż pracujące.

Wnioski: Wyniki badania wskazują, że w praktyce klinicznej należałoby uwzględnić optymizm i podejmowane strategie radzenia sobie z bólem. Szczególną uwagę trzeba zwracać na osoby chore na RZS, które wykazują negatywne oczekiwania determinujące u nich silny przewlekły ból bez względu na podejmowaną aktywność zaradczą. Skuteczną strategią może być wzmacnianie pozytywnych oczekiwań względem leczenia oraz poszukiwanie korzyści w aktualnej sytuacji zdrowotnej.

Pain is both a major symptom and a stressor in patients coping with rheumatoid arthritis (RA) [1]. According to the biopsychosocial model of unpleasant sensory impression, pain is a multidimensional phenomenon, which comprises physiological (sensation-related factors), psychological (affective) and social (socio-economic status, social support) factors [2]. Personality, emotions, cognitive processes and behaviour belong to a range of psychological factors impacting reactions to unpleasant sensory impressions. Researchers so far have mainly focused on phenomena increasing the pain sensation, such as negative affectivity, anxiety sensitivity, illness/injury sensitivity [3], negative emotions (depression, anxiety, helplessness) [2], and catastrophizing (coping behaviour; an exaggerated negative response to actual or anticipated pain) [4]. On the other hand, very few studies have examined psychological factors preventing pain, conceptualized as coping recourses which play a significant role in adaptation to chronic disease [e.g. 5]. These include optimism and pain coping strategies.

The concept of coping draws on, among others, the stress model by Lazarus and Folkman [6], in which it is defined as 'cognitive and behavioural efforts to manage specific external or internal demands'. Coping behaviours represent a variety of modes whose function is to modify and manage the problem (problem-focused coping) and/or to down-regulate emotional reactions of individuals (emotion-focused coping). Studies on pain coping define it as efforts undertaken by patients in order to minimize, reduce, or tolerate the experience of pain [7]. One of the aspects of coping effectiveness is the controllability of a challenging situation, defined as perceived ability to determine outcomes of an event [8].

Chronic pain in RA is considered as an uncontrollable stressor [1], which implies low ability to determine its course and outcomes by self-care options [9]. Therefore emotion-focused coping rather than problem-focused coping might be more effective and beneficial for this group of patients [1]. This is because the problem-coping approach in an uncontrollable context can only increase the risk of maladaptation and frustration [10]. Nevertheless, studies on the cognitive and behavioural strategies reducing unpleasant sensations in RA do not result in clearly defined outcomes [1]. The positive role of cognitive reframing (positive self-statements), distancing oneself from pain [11] and emotional expression [12] has been proven only in a few studies, whereas other studies have not confirmed the adaptive role of those behaviours at all [1]. However, there is clear evidence that inactivity and avoidance were associated with negative outcomes [13].

Dispositional optimism defined by Scheier and Carver [14] as positive outcome expectancies is summarised in the belief that one will generally experience good outcomes in life. Patients with positive outcome expectancies are more engaged in taking up health-oriented behaviours, even if this involves dealing with obstacles and challenges [9]. The significance of optimism in the experience of pain is due to its influence on coping strategies. This is because optimists tend to engage in problem-solving strategies (solving difficult problems) [15] whereas pessimists prefer avoidance, denial [16] and catastrophization [4]. This disposition stems from a flexible coping ability [17], because in the context of an uncontrollable situation optimists apply cognitive coping strategies such as acceptance, a sense of humour or positive reformulation of a challenge [16]. Optimistic patients with RA less often draw on emotional coping, which positively contributes to reduction of fear and depression [9]. Generally, RA optimistic patients [18] report better psychosocial and physical functioning.

The aim of the study was to verify the role of optimism and pain coping strategies in pain intensity among women with RA. The variables analysed included optimism, pain coping strategies (such as diverting attention, reinterpreting pain sensations, catastrophizing, ignoring pain sensations, praying or hoping, coping self-statements, increasing activity level) and average pain intensity during the 7 days of hospitalisation. 


\section{Material and methods \\ Design and sample}

The sample comprised 54 female patients aged 24-65 ( $M=52.07$; SD = 9.91). 66\% of the sample were high school or university graduates; nearly $76 \%$ were in a relationship; only $18 \%$ were employed; and most (79\%) described their economic status as average. The mean duration of disease was 11.43 years $(S D=8.41)$. The most common co-existing rheumatological disease was osteoarthritis (50\%; $n=27$ ) whilst morning stiffness lasted on average for approximately 97 minutes (SD $=139.35$ ).

The study was carried out in the Institute of Rheumatology in Warsaw $(n=26)$ and at the Department of Rheumatology, Regional Specialist Hospital in Częstochowa $(n=28)$. The demographic variables, optimism level and generic pain coping strategies were measured during the course of the study. Throughout the course of 7 days at $6.20 \mathrm{pm}$, the patients measured their pain intensity; they were reminded to do so by a short text message. The groups did not differ with regards to demographic, medical and major variables.

The study was approved by the Bioethical Commission of the Institute of Rheumatology.

\section{Measures}

\section{Optimism}

Optimism was measured by the Life Orientation Test (Life Orientation Test-Revised; Scheier, Carver and Bridges, Polish translation by Juczyński) [19].

The tool is composed of 10 items, including 6 measuring dispositional optimism ('In uncertain times, I usually expect the best') and 4 filler items.

Each variable is assessed by a participant on a 5-point scale where 0 stands for 'I disagree a lot', and where 4 refers to 'I agree a lot'. The higher the result is, the higher the level of optimism. Cronbach's $\alpha$ value in the present study was .71 .

\section{Pain coping strategies}

The assessment of reactions towards pain was carried out only once using the Coping Strategies Questionnaire (CSQ; Rosenstiel and Keefe, Polish adaptation by Juczyński) [19], which is composed of 42 questions.

There are 7 types of strategies: diverting attention ('I try to think about something pleasant'; 6 items); reinterpreting pain sensations ("I imagine that the pain is outside of my body'; 6 items); catastrophizing ('It's terrible and I feel it's never going to get better'; 6 items); ignoring pain sensations ('I don't think about the pain'; 6 items); praying or hoping ('I pray for the pain to stop'; 6 items); coping self-statements ('I see it as a challenge and don't let it bother me'; 6 items) and increasing activity level ('I do anything to get my mind off the pain'; 6 items). The higher the result is in a given sub-scale, the more often coping strategies occur in a group. The Cronbach alphas ranged from 0.63 (diverting attention) to 0.82 (catastrophizing, coping self-statements), indicating acceptable reliabilities.

\section{Pain}

For 7 consecutive days during hospitalization, participants used a 10-cm visual analogue scale (VAS; ranging from 0 - "no pain" to 10 - "the worst possible pain") to rate their average level of pain for the day. For analytical purposes, the pain measure is the average of the sum scored across the span of 7 days.

\section{Statistical analysis}

In the first stage of analysis, the Pearson correlations were computed between the main variables (optimism, pain coping strategies, pain intensity).

To investigate the differences in the experience of pain intensity as determined by the level of optimism and pain coping strategies, a series of two-way analyses of variance (ANOVAs) was conducted. Optimism and coping strategies were the independent variables (dichotomized at their means), and the average pain intensity was the dependent variable. A 2 (optimism: low vs. high) $\times 2$ (pain coping strategies: low vs. high) ANOVA tested whether the four groups varied in pain intensity, and the confounding background variables were entered into these analyses. Analyses were conducted using the program IBM SPSS 21.

\section{Results}

Firstly, descriptive statistics and simple correlations between main variables (optimism, pain coping strategies, pain intensity) were identified (Table I).

The results showed that optimism did not correlate with pain, but did enhance coping self-statements, increasing activity level and reducing catastrophizing. Only two coping strategies were correlated negatively with pain - ignoring pain sensations (moderate correlation) and coping self-statements (weak correlation). This means that attempts at minimizing pain sensations, as well as the conviction that one can cope with pain, significantly reduced the actual experience of pain. Furthermore, praying or hoping was the most commonly used strategy, whose intensity varied greatly from the intensity of coping self-statements (second most common coping strategy; $\mathrm{t}(53)=-291.13 ; p<0.001)$.

Detailed analyses of the relations between coping strategies and intensity of pain in the consecutive days 
Table I. Descriptive statistics and the Pearson correlations of main variables $(n=54)$

\begin{tabular}{|c|c|c|c|c|c|c|c|c|c|c|c|}
\hline & Variables & $M(S D)$ & 1. & 2. & 3. & 4. & 5. & 6. & 7. & 8. & 9. \\
\hline 1. & Optimism & $14.33(4.58)$ & & 0.12 & 0.01 & $-0.53^{\star \star}$ & 0.19 & 0.10 & $0.38^{\star *}$ & $0.28^{*}$ & -0.23 \\
\hline 2. & Diverting Attention & $17.85(6.53)$ & & & $0.52^{\star \star}$ & -0.02 & $0.37^{\star \star}$ & $0.44^{\star \star}$ & $0.49^{\star *}$ & $0.71^{\star \star}$ & -0.11 \\
\hline 3. & $\begin{array}{l}\text { Reinterpreting } \\
\text { Pain Sensations }\end{array}$ & $8.84(6.85)$ & & & & 0.01 & $0.58^{\star \star}$ & 0.26 & $0.52^{\star *}$ & $0.42^{* \star}$ & -0.10 \\
\hline 4. & Catastrophizing & $13.43(7.91)$ & & & & & -0.23 & 0.17 & $-0.30^{\star}$ & -0.23 & 0.21 \\
\hline 5. & Ignoring Pain Sensations & $13.54(7.55)$ & & & & & & 0.10 & $0.69^{* \star}$ & $0.56^{\star \star}$ & $-0.33^{*}$ \\
\hline 6. & Praying or Hoping & $21.40(7.27)$ & & & & & & & $0.32^{*}$ & 0.24 & -0.11 \\
\hline 7. & Coping Self-statements & $20.06(7.81)$ & & & & & & & & $0.70^{\star *}$ & $-0.28^{\star}$ \\
\hline 8. & Increasing Activity Level & $19.35(7.00)$ & & & & & & & & & -0.22 \\
\hline 9. & Pain & $4.05(2.06)$ & & & & & & & & & \\
\hline
\end{tabular}

${ }^{*} p<0.05 ;{ }^{* *} p<0.01 ;{ }^{* * *} p<0.001$

of the study proved moderate correlations between coping and unpleasant sensory experience only during the first 3 days of the research.

Secondly, to investigate whether the pain intensity depends on the level of optimism and coping strategies, a series of two-factor analyses of variance was conducted. The models were adjusted for employment, because this variable significantly influenced the pain intensity (the employed felt stronger pain compared to those who did not work; $F(1,52)=5.01 ; p<0.05)$. In most of the tested models two-way ANOVAs revealed the main effect of optimism for average pain intensity $(p=\langle 0.01-0.06\rangle$; with the exception of the model ignoring pain sensation; $p=0.24$ ), which indicates that optimists generally declared a lower level of pain than persons with a low level of this disposition.

Furthermore, there was a significant interaction between optimism and catastrophizing $[F(1,50)=4.51$; $p<0.05$; partial $\eta=0.08$ ] (Fig. 1). This effect did not change after adjusting for employment. Testing of main effects indicates that optimism differentiates the degree of pain, but only among those who rarely apply catastrophization $(p<0.01)$. In other words, the higher the level of optimism is, the lower the level of pain in this particular group. In the case of individuals with a tendency to catastrophize, the level of pain did not rely on the level of optimism.

A 2 (optimism: low vs. high) $\times 2$ (increasing activity level: low vs. high) ANOVA revealed a significant interaction between optimism and this coping strategy for pain $(F(1,49)=7.97 ; p<0.01$; partial $\eta=0.14)$. This proves a lower level of pain among optimists who apply an increasing activity level compared to pessimists $(p<0.05)$ and optimists who rarely get involved in this type of behaviour $(p<0.01)$ (Fig. 2)
None of the tested models showed significant effects of major coping strategies, which means that individuals who took up an activity more often experienced the same level of pain as those who did not (or did so rarely).

\section{Discussion}

The main aim of the study was to explore the influences of optimism and pain coping strategies on pain intensity in female RA patients during hospitalization. Optimism enhanced active type of coping (coping self-statements) and distancing from pain (increasing activity level), reducing the tendency to exaggerate its

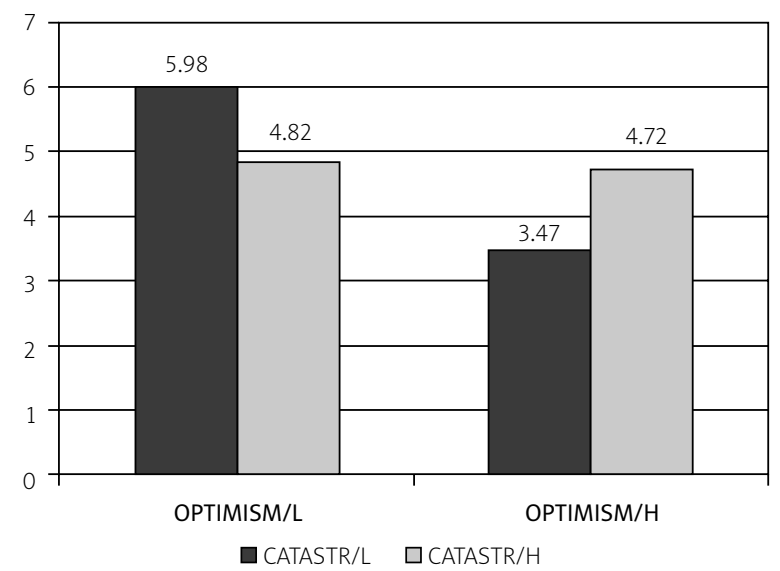

OPTIMISM/L - low level of optimism; OPTIMISM/H - high level; CATASTR/L - low level of catastrophizing; CATASTR/H - high level of catastrophizing; the model was adjusted for employment $=0.33$

Fig. 1. Levels of pain depending on Optimism and Catastrophization (ANOVA). 


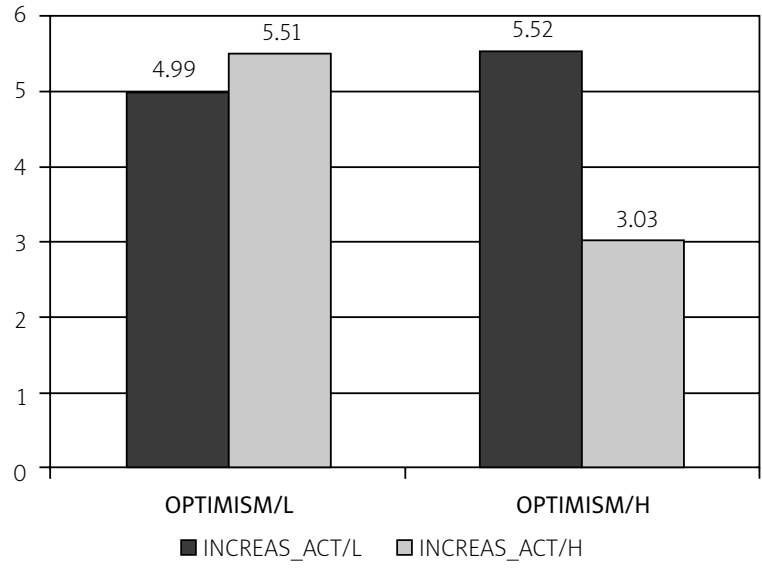

OPTIMISM/L - low level of optimism; OPTIMISM/H - high level; INCREAS_ACT/L - low level of increasing activity level; CATASTR/H - high level of increasing activity level; the model was adjusted for employment $=0.33$

Fig. 2. Levels of pain depending on Optimism and Increasing Activity Level (ANOVA).

negative impact on overall functioning in life (catastrophizing).

It was only coping self-statements and ignoring pain sensations which lowered the intensity of pain. Results indicate that positive outcome expectancies favour adaptive forms of behaviour when experiencing chronic pain. Moreover, more detailed analyses prove similar correlations between the above coping strategies, alongside increasing activity level, and pain intensity during the first three days of hospitalization. The results can also be interpreted as a limited impact of pain coping strategies on the pain sensation, and as the possible involvement of other factors in its intensification, i.e. the lack of illness control among the patients. Patients with RA expect their health to be controlled by their doctor, which in turn diminishes their ability to draw on their own coping possibilities [9]. What partially confirms this thesis is the fact that praying or hoping was the most commonly used coping strategy in this study. On the other hand, lack of confidence may lead to depression, and consequently it may intensify physical impairment [20].

Furthermore, the results may be due to the deficiencies of the commonly used scale CSQ, which does not include items referring to direct coping with pain, i.e. taking medications, or consultation with a doctor.

No direct correlation was detected between optimism and pain (either with regards to its average intensity, or with regards to its daily level), but it was nevertheless proven that the optimists experienced less pain than the pessimists. This seemingly contradictory result may indicate a curvilinear correlation among the variables.
The study also tested adaptive behaviours for persons with low versus high levels of optimism. It was found that individuals with stronger positive expectations felt a lower degree of pain compared to those who did not have those positive expectations. What was beneficial for this particular group was the increasing activity level and rare catastrophization.

The results emphasize the role of adjusting the type of behaviour according to the degree of optimism in order to maximize the effectiveness of the activities taken up.

On the other hand, maladjustment of coping strategies and psychological features (in this case, a low level of catastrophization and strong increase in activity level among pessimists and a small increase in activity level among optimists) resulted in pain intensification.

What is interesting here is that the degree of pain among pessimists did not depend on the coping strategies employed, which demonstrates that negative outcome expectancies are a determining factor here. From the point of view of clinical practice, it is this particular group which needs special care. Remaining optimistic and seeking benefits in the RA experience may have a positive impact on one's activities, and, consequently, on better adaptation to the experience of illness [17]. The research indicates that therapeutic interventions such as teaching patients problem-solving skills, a focus on reducing negative expectations, and cognitive pain coping skills training are beneficial in pain management and reduction in psychological distress for RA patients [21].

The results showing that praying or hoping is the most commonly used pain coping strategy may be explained in terms of the character of hospitalization whereby control over health is handed over to medical professionals. This type of behaviour was usually positively correlated with age [2]. However, this correlation was not observed in our study.

The research demonstrates that people in employment experienced stronger pain than those who did not work. The result was quite the opposite in earlier studies carried out in other European countries only on people in employment, in which pain made them unable to work [22]. Therefore the results can be interpreted in the specific context of the labour market in Poland, and the fact that the study was carried out on two sample groups.

It would be recommended to carry out future studies in a naturalistic setting, including other significant variables for pain (e.g. daily illness symptoms, health condition, disease progression). Analyses based on a bigger sample and the inclusion of a control group would perhaps bring about more clearly defined data on the topic associations between psychological factors and pain intensity. Additionally, the limitation of the sam- 
ple to women precludes generalization of the findings to men with chronic pain. Moreover, the results showed the differences in pain intensity and in the pain coping strategy use between women and men [23]. Despite the constraints listed above, the obtained results may contribute to broadening our understanding of the role performed by optimism in the coping processes with chronic pain in women.

\section{Conclusions}

To conclude, the results of the study indicate that in clinical practice in RA care one should take into account the degree of optimism and pain coping strategies.

Given that optimists and pessimists differ in terms of the level of pain they experience, and given that activities they take up (catastrophizing and increasing activity level) bring about different results, the transmission of information regarding the illness, communication with a patient and treatment should all be different. Intensification of positive expectations and seeking benefits in the RA experience alongside verbalisation of one's feelings towards pain among female patients with negative expectations may bring about positive results.

The study was co-financed by the Polish Ministry of Science and Higher Education core funding for Statutory Research in the University of Social Sciences and Humanities, Faculty of Psychology, 25504/E-560/M/2013.

\section{References}

1. Newth S, Delongis A. Individual differences, mood, and coping with chronic pain in Rheumatoid Arthritis: A daily process analysis. Psychol Health 2004; 19: 283-305.

2. Keefe FJ, Smith SJ, Buffington AL, et al. Recent advances and future directions in the biopsychosocial assessment and treatment of arthritis. J Consult Clin Psychol 2002; 70: 640-655.

3. Gatchel RJ, Peng YB, Peters ML, et al. The biopsychosocial approach to chronic pain: scientific advances and future directions. Psychol Bull 2007; 133: 581-624.

4. Sullivan MJ. The pain catastrophizing scale: Development and validation. Psychol Assess 1995; 7: 524-532.

5. Pakenham KI, Rinaldis M. The role of illness, resources, appraisal, and coping strategies in adjustment to HIV/AIDS: The direct and buffering effects. J Behav Med 2001; 24: 259-279.

6. Lazarus RS, Folkman, S. Stress, appraisal, and coping. Springer, New York 1984.

7. Keefe FJ, Caldwell DS, Queen KT, et al. Pain coping strategies in osteoarthritis patients. J Consult Clin Psychol 1987; 55: 208-212.

8. Eitel P, Hatchett L, Friend R, et al. Burden of self-care in seriously ill patients: impact on adjustment. Health Psychol 1995; 14: 457-463.

9. Fournier M, De Ridder D, Bensing J. Optimism and adaptation to chronic disease: The role of optimism in relation to self-care options of type 1 diabetes mellitus, rheumatoid arthritis and multiple sclerosis. Br J Health Psychol 2002; 7: 409-432.

10. Affleck G, Pfeiffer C, Tennen H, et al. Attributional processes in rheumatoid arthritis patients. Arthritis Rheum 1987; 30 : 927-931.

11. Watkins KW, Shifren K, Park DC, et al. Age, pain, and coping with rheumatoid arthritis. Pain 1999; 82: 217-228.

12. Kerns RD, Rosenberg R, Jacob MC. Anger expression and chronic pain. J Behav Med 1994; 17: 57-67.

13. Ramjeet J, Smith J, Adams M. The relationship between coping and psychological and physical adjustment in rheumatoid arthritis: a literature review. J Clin Nurs 2008; 17: 418-428.

14. Scheier MF, Carver CS. Optimism, coping, and health: Assessment and implications of generalized outcome expectancies. Health Psychol 1985; 4: 219-247.

15. Novy DM, Nelson DV, Hetzel RD, et al. Coping with chronic pain: sources of intrinsic and contextual variability. J Behav Med 1998; 21: 19-34.

16. Terrill AL, Ruiz JM, Garofalo JP. Look on the bright side: do the benefits of optimism depend on the social nature of the stressor? J Behav Med 2010; 33: 399-414.

17. Carver ChS, Scheier MF, Segerstrom SC. Optimism. Clin Psychol Rev 2010; 30: 879-889.

18. Brenner GF, Melamed BG, Panush RS. Optimism and coping as determinants of psychosocial adjustment to rheumatoid arthritis. J Clin Psychol Med Settings 1994; 1: 115-134.

19. Juczyński Z. Narzędzia do pomiaru w promocji i psychologii zdrowia. Pracownia Testów Psychologicznych, Warszawa 2009.

20. Neugebauer A, Katz PP, Pasch LA. Effect of valued activity disability, social comparisons, and satisfaction with ability on depressive symptoms in rheumatoid arthritis. Health Psychol 2003; 22: 253-262.

21. Taylor SE. Health Psychology (8 ${ }^{\text {th }}$ Edition). McGraw Hill, New York 2012.

22. Patel AS, Farquharson RC, Dawn M, et al. The impact and burden of chronic pain in the workplace: A qualitative systematic review. Pain Pract 2012; 12: 578-589.

23. Keefe FJ, Lefebvre JC, Egert J, et al. The relationship of gender to pain, pain behavior, and disability in osteoarthritis patients: The role of catastrophizing. Pain 2000; 87: 325-334. 